\title{
Effect of Lactation Stage on the Odd- and Branched-Chain Milk Fatty Acids of Dairy Cattle Under Grazing and Indoor Conditions
}

\author{
M. Craninx, ${ }^{*}$ A. Steen, ${ }^{*}$ H. Van Laar,† T. Van Nespen, ${ }^{*}$ J. Martín-Tereso,† B. De Baets,‡ and V. Fievez ${ }^{* 1}$ \\ *Laboratory for Animal Nutrition and Animal Product Quality, Ghent University, Proefhoevestraat 10, 9090 Melle, Belgium \\ †Nutreco Ruminant Research Centre, Veerstraat 38, 5831 JN Boxmeer, the Netherlands \\ ‡Department of Applied Mathematics, Biometrics and Process Control, Ghent University, Coupure links 653, 9000 Ghent, Belgium
}

\section{ABSTRACT}

The pattern of odd- and branched-chain fatty acids (OBCFA) in milk fat reflects rumen microbial activity and proportions of different rumen microbial groups. Therefore, these milk fatty acids (FA) are used to predict rumen proportions of volatile fatty acids, duodenal flow of microbial protein, and occurrence of rumen acidosis. However, current models do not correct for the potential effects of lactation stage on the level of OBCFA in milk fat. Hence, the objectives of this study were 1) to describe progressive changes related to lactation stage in concentrations of milk FA, with emphasis on the OBCFA, using the incomplete gamma function of Wood, and 2) to analyze whether lactation curves of milk FA on the one hand and milk production or milk fat content on the other hand coincide through evaluation of the correlation between the parameters of the Wood functions fitted to individual animal data. Data were collected from 2 trials in which milk FA during lactation were monitored. The first experiment was a stable trial with 2 groups of 10 cows receiving 2 dietary treatments from wk 1 to 40 of lactation. The second experiment was a grazing trial with 9 cows that were followed during the first 18 wk of lactation. Lactation curves of milk production, milk fat content, and individual milk FA were developed using the incomplete gamma function of Wood for each of the 3 dietary strategies separately. For almost all of the milk FA, lactation curve shapes were similar for all 3 dietary treatments. The OBCFA with chain lengths of 14 and 15 carbon atoms followed the lactation curves of the short- and medium-chain milk FA, which increased in early lactation. The OBCFA with chain length of 17 carbon atoms decreased during the early lactation period, following the pattern of milk longchain fatty acids. The short- and medium-chain milk FA and OBCFA in the early lactation period seemed

Received August 31, 2007.

Accepted February 29, 2008.

${ }^{1}$ Corresponding author: veerle.fievez@UGent.be to be negatively correlated with the starting milk production and milk fat content, but correlations were modest. Information of milk FA lactation curves should be incorporated in predictive and classification models based on these milk FA, to improve their performance.

Key words: lactation stage, milk fatty acid, incomplete gamma function of Wood

\section{INTRODUCTION}

Fatty acids (FA) in milk fat can be divided into different groups, based on the metabolic pathways of their production. Short- and medium-chain milk FA (SMCFA; C4:0-C14:0 and approximately half of C16:0) are the result of de novo synthesis in the mammary gland. $\beta$-Hydroxybutyrate and particularly acetate originating from ruminal fermentation are the major sources for this de novo FA synthesis. The remaining C16:0 and almost all of the long-chain milk FA (LCFA; C18:0-C22:0) originate from circulating blood lipids, after absorption from the small intestine or mobilization from adipose tissue. The odd- and branched-chain fatty acids (OBCFA) in milk fat are largely derived from bacteria leaving the rumen, and variations in the OBCFA profile are mainly due to changes in relative abundance of specific rumen bacteria. However, linear odd-chain FA (C15:0 and C17:0) might be partially synthesized de novo in the mammary gland and animal tissues from propionate (Massart-Leën et al., 1983; Vlaeminck et al., 2006b; Cabrita et al., 2007) although the proportion of de novo synthesized odd-chain FA has been suggested to be negligible (Croom et al., 1981). Fatty acids with chain length of 14 to 18 carbons might be further modified in the mammary gland through the activity of $\Delta^{9}$-desaturase (Grummer, 1991).

Milk FA composition also seems to be influenced by the stage of lactation (Palmquist et al., 1993; Kelsey et al., 2003; Kay et al., 2005; Garnsworthy et al., 2006). At the onset of lactation, cows are most often mobilizing adipose FA, which are partially incorporated into 
Table 1. Intake (mean \pm SD) and chemical composition of compound feeds used in the 3 dietary treatments

\begin{tabular}{|c|c|c|c|c|c|c|}
\hline \multirow[b]{3}{*}{ Compound feed } & \multicolumn{3}{|c|}{ Stable trial } & & & \\
\hline & \multicolumn{2}{|c|}{ Control diet } & \multirow{2}{*}{$\begin{array}{c}\text { Test diet } \\
\text { Mixed }\end{array}$} & \multicolumn{3}{|c|}{ Grazing trial } \\
\hline & $\begin{array}{c}\text { Balanced } \\
\text { concentrate }^{1}\end{array}$ & $\begin{array}{l}\text { Protein } \\
\text { corrector }^{1}\end{array}$ & & $\begin{array}{l}\text { Balanced } \\
\text { concentrate }^{1}\end{array}$ & $\begin{array}{l}\text { Protein } \\
\text { corrector }^{1}\end{array}$ & $\begin{array}{l}\text { Extruded } \\
\text { linseed }^{2}\end{array}$ \\
\hline Average intake $^{3}(\mathrm{~kg}$ of $\mathrm{DM} / \mathrm{d})$ & \multicolumn{2}{|c|}{$6.78 \pm 2.04(\mathrm{n}=357)$} & \multirow{2}{*}{$17.15 \pm 4.37(\mathrm{n}=399)$} & \multicolumn{2}{|c|}{$4.53 \pm 1.68(\mathrm{n}=126)$} & $1.23 \pm 0.37(\mathrm{n}=70)$ \\
\hline $\mathrm{VEM}^{4}(\mathrm{VEM} / \mathrm{kg}$ of product) & 1,160 & 1,145 & & 960 & 930 & 1,682 \\
\hline $\mathrm{DVE}^{5}$ (g/kg of product) & 153 & 256 & 113 & 100 & 200 & 174 \\
\hline Crude fat (g/kg of product) & 58 & 39 & 43 & 60 & 32 & 240 \\
\hline Crude ash ( $\mathrm{g} / \mathrm{kg}$ of product) & 75 & 111 & 84 & 80 & 112 & 49.6 \\
\hline Crude fiber (g/kg of product) & 98 & 62 & 139 & 116 & 79 & 90.7 \\
\hline
\end{tabular}

\footnotetext{
${ }^{1}$ Proportions of balanced concentrate and protein corrector varied according to the animal's requirements in relation to individual milk yield and physiological status.

${ }^{2}$ Averages calculated based on period when extruded linseed product (Nutex, Interagri-Dumoulin, Seilles, Belgium) was fed (July 8October 7).

${ }^{3} \mathrm{n}=$ number of observations used to calculate intake of the compound feeds.

${ }^{4} 1,000 \mathrm{VEM}=6.9 \mathrm{MJ}$ of $\mathrm{NE}_{\mathrm{L}}$ (van Es, 1978).

${ }^{5} \mathrm{DVE}=$ digestible protein in the small intestine (Tamminga et al., 1994).

${ }^{6} \mathrm{OEB}=$ degraded protein balance, reflecting the difference between the potential microbial protein synthesis based on degraded feed CP and that based on energy available for microbial fermentation in the rumen (Tamminga et al., 1994).
}

milk fat (Palmquist et al., 1993). The greater uptake of LCFA during this period decreases the proportion of SMCFA in milk fat, due to both a dilution effect and inhibition of de novo synthesis of FA (Chilliard et al., 2000). Therefore, proportions of SMCFA are relatively low in the beginning of the lactation and increase until at least 8 to $10 \mathrm{wk}$ into lactation (Palmquist et al., 1993; Chilliard et al., 2000), whereas the proportions of LCFA progressively decrease in the early lactation period. Although concomitant changes in SMCFA and LCFA in relation to lactation stage are well described, there is a lack of knowledge on the effect of lactation stage on the OBCFA.

Milk FA and especially OBCFA are currently used to monitor rumen function in predictive as well as classification models. Total OBCFA secretion and proportions in milk fat were related to duodenal flow of microbial protein (Vlaeminck et al., 2005) and the rumen fermentation pattern (Vlaeminck et al., 2006a; Craninx et al., 2008). Currently, we are exploring the potential of the milk FA profile to detect metabolic disorders in lactating cows (e.g., Van Nespen et al., 2005). To appropriately monitor rumen function, models based on milk OBCFA should be valid at different lactation stages, with special emphasis on the earlylactation period for diagnostic models, because cows are then most sensitive to metabolic disorders. The first aim of this paper is therefore to describe progressive changes in milk OBCFA as a function of lactation stage. The approach is based on the incomplete gamma function of Wood, referred to as the Wood function (Wood, 1967), which appropriately describes milk pro- duction and body weight changes as a function of lactation stage (Macciotta et al., 2005; Quinn et al., 2005, 2006; Choumei et al., 2006). This study assesses whether the Wood function is also applicable to describe milk OBCFA changes as a function of lactation stage. The second aim is to assess whether changes in milk FA and particularly OBCFA coincide with changes in milk production or milk fat content as a function of lactation stage.

\section{MATERIALS AND METHODS}

\section{Experimental Design and Diets}

This study combined data from a stable and grazing trial. The chemical composition of the diets is given in Tables 1 and 2. The stable trial was conducted at the Nutreco Ruminant Research Centre (Boxmeer, the Netherlands) from June 2005 through September 2006 . The grazing trial was conducted on a commercial farm (Flanders, Belgium) from May to October, 2004.

Experiment 1 (Stable Trial). This experiment was set up to test 2 dietary strategies and their effects on the milk FA pattern throughout the complete lactation cycle (wk 1 to 40 of lactation). Twenty-one high-yielding lactating Holstein cows from the Nutreco Ruminant Research Centre were divided into the 2 dietary strategies (10 on the control diet and 11 on the test diet). During the experiment, 4 cows became sick (3 cows on the control diet and 1 cow on the test diet). Data from 3 cows ( 1 on the test diet and 2 on the control diet) were completely omitted from the data 
Table 2. Intake (mean \pm SD) and chemical composition of the main forages used in the 3 dietary treatments

\begin{tabular}{|c|c|c|c|c|c|c|c|}
\hline \multirow[b]{3}{*}{ Forage $^{1}$} & \multicolumn{4}{|c|}{ Stable trial } & & & \\
\hline & \multicolumn{2}{|c|}{ Control diet } & \multicolumn{2}{|c|}{ Test diet } & \multicolumn{3}{|c|}{ Grazing trial } \\
\hline & Corn silage & Grass silage & Grass silage & Hay & Fresh grass & Corn silage & Straw \\
\hline $\begin{array}{l}\text { Average intake }{ }^{2} \\
(\mathrm{~kg} \text { of } \mathrm{DM} / \mathrm{d})\end{array}$ & $\begin{array}{c}8.00 \pm 1.81 \\
(\mathrm{n}=356)\end{array}$ & $\begin{array}{c}5.33 \pm 1.21 \\
(\mathrm{n}=356)\end{array}$ & $\begin{array}{c}2.61 \pm 1.13 \\
(\mathrm{n}=400)\end{array}$ & $\begin{array}{c}3.92 \pm 1.70 \\
(\mathrm{n}=400)\end{array}$ & Ad libitum & $\begin{array}{c}5.92 \pm 1.12 \\
(\mathrm{n}=126)\end{array}$ & $\begin{array}{c}0.44 \pm 0.08 \\
(\mathrm{n}=15)\end{array}$ \\
\hline DM (g/kg of product) & 376 & 369 & 369 & 872 & 209 & 329 & 840 \\
\hline $\mathrm{VEM}_{3}(\mathrm{VEM} / \mathrm{kg}$ of DM $)$ & 976 & 925 & 925 & 799 & 978 & 910 & 517 \\
\hline $\mathrm{CP}(\mathrm{g} / \mathrm{kg}$ of $\mathrm{DM})$ & 66.7 & 199 & 199 & 87.0 & 230 & 78.5 & 41.0 \\
\hline Crude fat ( $\mathrm{g} / \mathrm{kg}$ of $\mathrm{DM})$ & 31.0 & 43.3 & 43.3 & 40.0 & $\mathrm{ND}^{6}$ & ND & ND \\
\hline Crude ash (g/kg of DM) & 32.0 & 131 & 131 & 57.3 & 106 & 49.0 & 60.0 \\
\hline Crude fiber (g/kg of DM) & 200 & 242 & 242 & 303 & 216 & 216 & 435 \\
\hline
\end{tabular}

${ }^{1}$ Forage intake varied according to their availability (e.g., fresh grass yield on pasture) and the dairy cow's requirements as a function of the individual milk yield and lactation stage. Energy and protein requirements were based on the Dutch-Belgian VEM (feed unit milk; van Es, 1978) and DVE (protein digestible in the small intestine) system (Tamminga et al., 1994), respectively.

${ }^{2} \mathrm{n}=$ number of observations used to calculate average intake of the forages.

${ }^{3} 1,000 \mathrm{VEM}=6.9 \mathrm{MJ}$ of $\mathrm{NE}_{\mathrm{L}}$ (van Es, 1978).

${ }^{4} \mathrm{DVE}=$ digestible protein in the small intestine (Tamminga et al., 1994).

${ }^{5} \mathrm{OEB}=$ degraded protein balance, reflecting the difference between the potential microbial protein synthesis based on degraded feed CP and that based on energy available for microbial fermentation in the rumen (Tamminga et al., 1994).

${ }^{6} \mathrm{ND}=$ not determined.

set because they became sick during early lactation (lactation wk 4, 7, and 10). The fourth cow became sick in wk 22 of lactation and data until wk 21 were retained in the data set. Data of the following weeks were considered as missing values. During the experiment, it was decided to include 2 extra cows in the control group to balance the observations in both dietary treatments. For these cows, measurements were available from wk 5 through 40 of lactation. Data from the first $4 \mathrm{wk}$ of lactation were considered as missing values in the data set. In that manner, the control and test groups consisted of 10 cows each, including 8 primiparous and 12 multiparous cows.

The control dietary strategy corresponded to a standard Dutch diet, with ad libitum access to forage consisting of corn silage and grass silage $(600: 400$, wt/wt on a DM basis) and restricted access to a mixture of a balanced concentrate and a protein corrector, according to the animal's requirements (Table 1 and Table 2). The balanced concentrate consisted of rapeseed meal, maize, palm kernel expeller, beet pulp, gelatinized maize, citrus pulp, lupins, vinasses, molasses, soybean meal, fat, limestone, and minerals, in order of decreasing inclusion (Production feed, optimization code: 1996, HX-UTD, Boxmeer, the Netherlands), whereas the protein corrector consisted of soybean meal, molasses, limestone, fat, and minerals (Hepromix, optimization code 1995, HX-UTD).

The amount of compound feed given to the cows was gradually increased according to common practice in
Dutch dairy farming systems (Figure 1). These cows reached maximum intake of the compound feed after 7 wk of lactation. The cows on the test diet had ad libitum access to the forage, consisting of grass silage and hay (350:650, wt/wt on a DM basis), and ad libitum access to a test compound feed, which explains the high and relatively constant intake of the compound feed from the beginning of the lactation (Figure 1). The test compound consisted of maize gluten feed, beet pulp, soybean meal, maize, fiber source, wheat, soy hulls, wheat middlings, sunflower expeller, molasses, fat, limestone, and minerals in order of decreasing inclusion (Specialty feed, optimization code 2096, HX-UTD).

Milk samples were taken on Monday evening, Tuesday morning, Wednesday evening, and Thursday morning during lactation wk 1 to $10,14,18,22,32$, 36 , and 40. Morning and evening samples were pooled weekly per cow for milk FA analysis $(\mathrm{n}=320 ; 16 \mathrm{wk}$ $\times 20$ cows). Dry matter intake of the compound feed and forage as well as milk yield were registered daily and individually.

The chemical composition of the forages was determined by near infrared spectroscopy (BLGG, Oosterbeek, the Netherlands). The chemical composition of the compound feeds were calculated based on tabular values of individual ingredients (CVB, 2004).

Experiment 2 (Grazing Trial). The second experiment was set up to follow the milk FA pattern during the first 6 mo of the lactation cycle under grazing condi- 


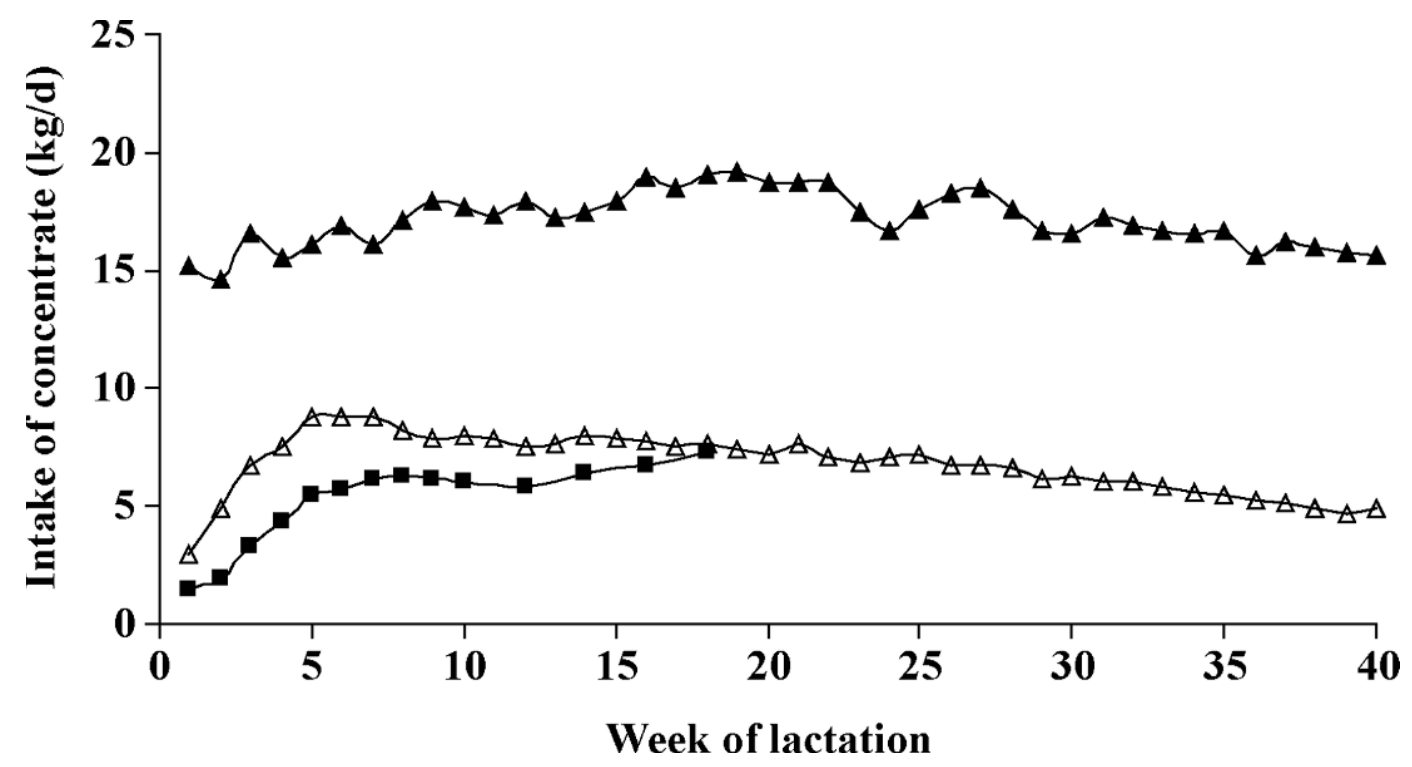

Figure 1. Intake of compound feed $(\mathrm{kg}$ of $\mathrm{DM} / \mathrm{d})$ for the cows receiving the control $(\triangle$ : lactation wk 1 to $40, \mathrm{n}=10)$ or the test dietary strategy ( $\mathbf{\Lambda}$ : lactation wk 1 to $40, \mathrm{n}=10)$ during the stable trial or involved in the grazing trial $(\boldsymbol{\square}$ : lactation wk 1 to $18, \mathrm{n}=9$ ).

tions. Nine lactating Holstein cows on a commercial farm (Flanders, Belgium) were used, including 3 primiparous and 6 multiparous cows. In addition to fresh grass, the cows received corn silage, straw, a protein corrector, and balanced concentrate, adjusted to the cow's individual requirements according to her milk yield (CVB, 2004). The protein corrector consisted of toasted soybean meal, rapeseed meal, rapeseed expeller, sunflower seed meal, beet molasses, and fat in order of decreasing inclusion (Aminolac 38 Extra, Aveve, Leuven, Belgium). The balanced concentrate consisted of rapeseed meal, soy hulls, maize gluten feed, wheat middlings, beet molasses, wheat, toasted soybean meal, palm kernel expeller, and palm oil in order of decreasing inclusion (Glucolac 21, Aveve). This farm was involved in a commercial project to increase levels of conjugated linoleic acid and n-3 FA in milk, which required supplementation of extruded linseed (Nutex, Interagri-Dumoulin, Seilles, Belgium) from July 8 (cows were then in lactation wk 5 to 10 ). This product was supplied with forage. Depending on the milk yield of cows, this product was also supplied individually together with the balanced concentrate.

Weekly, one morning and one evening milk sample was taken in lactation wk 1 through 10 , and wk 12 , 14, 16, and 18. Morning and evening milk samples were pooled for milk FA analysis. Dry matter intake of the forage and the protein corrector fed as a TMR in the stable was based on weights registered by the forage mixer and corrected for residuals. Individual intake was calculated as the average of the whole group. The intake of the balanced compound feed and the individually distributed linseed product was registered individually. Milk yield was registered daily and individually. Fresh grass samples were sampled according to Lourenço et al. (2007b) on a single day during the week of milk sampling and were analyzed by near infrared spectroscopy (BLGG). The chemical composition of straw was calculated based on tabular values (CVB, 2004).

\section{FA Analysis}

Milk was extracted, methylated, and analyzed by GLC as described by Vlaeminck et al. (2005). Briefly, in the first step, samples were extracted with ammonium hydroxide solution, ethanol, diethyl ether, and petroleum ether. In the second extraction step, ethanol, diethyl ether, and petroleum ether were used, and in the final extraction step, the solvents used were diethyl ether and petroleum ether. Extracts from the 3 consecutive steps were combined and evaporated using a rotary evaporator at room temperature, and the extracted lipids were resolved in $20 \mathrm{~mL}$ of diethyl ether and petroleum ether $(1: 1, \mathrm{vol} / \mathrm{vol})$. Tridecanoic acid (Sigma, Bornem, Belgium) was used as internal standard and added before methylation. The fatty acids in extracted lipids were methylated with $\mathrm{NaOH}$ in methanol ( $0.5 \mathrm{~mol} / \mathrm{L})$, followed by $\mathrm{HCl}$ in methanol (1:1, vol/ vol). The fatty acid methyl esters were extracted twice with $2 \mathrm{~mL}$ of hexane. From the extracts, $1 \mathrm{~mL}$ was analyzed separately for short-chain FA (C4:0 to C10:0) 
and medium- and long-chain FA (C12:0 to C24:0). Standard curves were used to determine the response factors for milk short-chain FA, taking into account tridecanoic acid (Sigma) as the internal standard. The methylated FA were analyzed on a Hewlett-Packard 6890 gas chromatograph (Hewlett-Packard Co, Brussels, Belgium) with a CP-Sil88 column for fatty acid methyl esters $(100 \mathrm{~m} \times 0.25 \mathrm{~mm} \times 0.2 \mu \mathrm{m}$; Chrompack Inc., Middelburg, the Netherlands).

\section{Calculations and Statistical Analysis}

Milk FA were expressed as proportion of total fatty acids ( $\mathrm{g} / 100 \mathrm{~g}$ of FA). Milk FA reported in the current study are limited to C4:0, C6:0, C8:0, C10:0, C12:0, $\mathrm{C} 14: 0, \mathrm{C} 16: 0, \mathrm{C} 18: 0$, iso C14:0, iso C15:0, iso C16:0, iso $\mathrm{C} 17: 0$, anteiso C15:0, C15:0, C17:0, C17:1 cis-9, C18:1 cis- 9 , C18:1 trans-10, C18:1 trans- $11, \mathrm{C} 18: 2$ cis9 trans-11, C18:2 n-6, and C18:3 n-3 as the most relevant. Anteiso C17:0 and C16:1 cis-9 coeluted, which impaired analysis of anteiso C17:0. All statistical analyses were performed using SPSS (SPSS software for Windows, release 11.0, SPSS Inc., Chicago, IL).

Least squares means of milk production $(\mathrm{kg} / \mathrm{d})$, milk fat content (g/100 g of milk), and milk FA ( $\mathrm{g} / 100 \mathrm{~g}$ of milk FA) per dietary strategy and lactation week were estimated using the linear mixed model (LMM) procedure according to

$$
Y_{i j k l}=\mu+L_{i}+P_{j}+D_{k}+L D_{i k}+c_{l}\left(D_{k}\right)+\varepsilon_{i j k l}
$$

where $Y_{i j k l}=$ milk production $(\mathrm{kg} / \mathrm{d})$, milk fat content (g/100 g of milk), or individual milk FA (g/100 g of milk FA), $L_{i}=$ effect of lactation week $i$ (repeated measure), $P_{j}=$ fixed effect of parity group $(1,2,>2), D_{k}=$ fixed effect of dietary strategy (control stable diet vs. test stable diet vs. grazing), $L D_{i k}=$ interaction between dietary strategy and lactation week, $c_{l}\left(D_{k}\right)=$ nested random effect of cow within dietary strategy, and $\varepsilon_{i j k l}=$ residual error.

Measures on the same animal close in time are often more correlated than measures further apart in time, which is referred to as covariation within animals (Littell et al., 1998). In the LMM, the variation between animals is specified as random factor $\left[c_{l}\left(D_{k}\right)\right]$, and the covariation within each animal is specified as the repeated measure, modeled using a first-order autoregressive structure with homogeneous variances [AR(1)]. The combination structure $\left[\mathrm{r}_{\mathrm{AR}(1)+\mathrm{RE}}{ }^{(\mathrm{lag})}\right]$ specifies an interanimal random effect of differences between animals and a correlation structure within animals that decreases with increasing lag between measures (Littell et al., 1998). This structure was assessed using Akaike's information criterion and proved to suit the data better than the simpler compound symmetry structure. The correlation function for the AR(1) plus random effect covariance structure is calculated as

$$
r_{A R(1)+R E^{(l a g)}}=\frac{\left[\sigma_{\text {animal }}^{2}+\sigma_{\text {residual }}^{2}\left(r_{A R(1)}\right)^{l a g}\right]}{\sigma_{\text {residual }}^{2}+\sigma_{\text {animal }}^{2}} .
$$

The estimated correlation functions from the AR(1) plus random effect covariance structures are presented for milk production, milk fat, and some individual milk FA, representative for different groups of milk FA, of which also lactation curves are presented. The correlation coefficients at lag $=1 \mathrm{wk}$ are included in Table 3, as well as the results of the linear mixed model.

The Wood function (Wood, 1967) was used to describe the lactation curves of milk production, milk fat content, and milk FA proportions in milk fat. Although many mathematical functions are mentioned in literature to model lactation curves, the Wood function is still widely used (Macciotta et al., 2005; Grzesiak et al., 2006; Quinn et al., 2006). The Wood model is a simple gamma function with only 3 parameters to be estimated. Therefore, this model was assessed first to describe milk FA concentrations in relation to lactation stage. Because the model fitted well to our data, it was decided to use this model, rather than further assessing more difficult models with more parameters to be estimated.

The algebraic form proposed by Wood, referred to as the incomplete gamma function of Wood or Wood function is

$$
Y(t)=a t^{b} e^{-c t},
$$

where $Y(t)$ is the milk production $(\mathrm{kg} / \mathrm{d})$, milk fat content $(\mathrm{g} / 100 \mathrm{~g}$ of milk), or individual milk FA $(\mathrm{g} / 100 \mathrm{~g}$ of milk FA) at lactation week $t, a$ is the parameter related to the initial milk production, milk fat content, or individual milk FA proportions or a scaling factor associated with the average value (Quinn et al., 2005), $b$ is the parameter related to the slope of the curve between calving and the maximum or minimum of the curve, and $c$ is the parameter related to the slope of the curve following this maximum or minimum (Quinn et al., 2005; Grzesiak et al., 2006). The time at peak of milk production, milk fat content, or proportions of individual milk FA can be calculated as $b / c$ weeks after calving. The peak value is calculated as $a(b /$ $c)^{b} e^{-b}$.

The Wood function was fit for the 3 dietary strategies separately using the nonlinear regression technique of SPSS. All the individual observations were used in 
Table 3. Average milk production ( $\mathrm{kg} / \mathrm{d})$, milk fat content ( $\mathrm{g} / 100 \mathrm{~g}$ of milk), and individual milk fatty acids (FA; g/100 g of milk FA) per dietary strategy or parity group as well as effect of parity, dietary strategy (DS), lactation week (LW), and the interaction (DS $\times$ LW) ${ }^{1}$

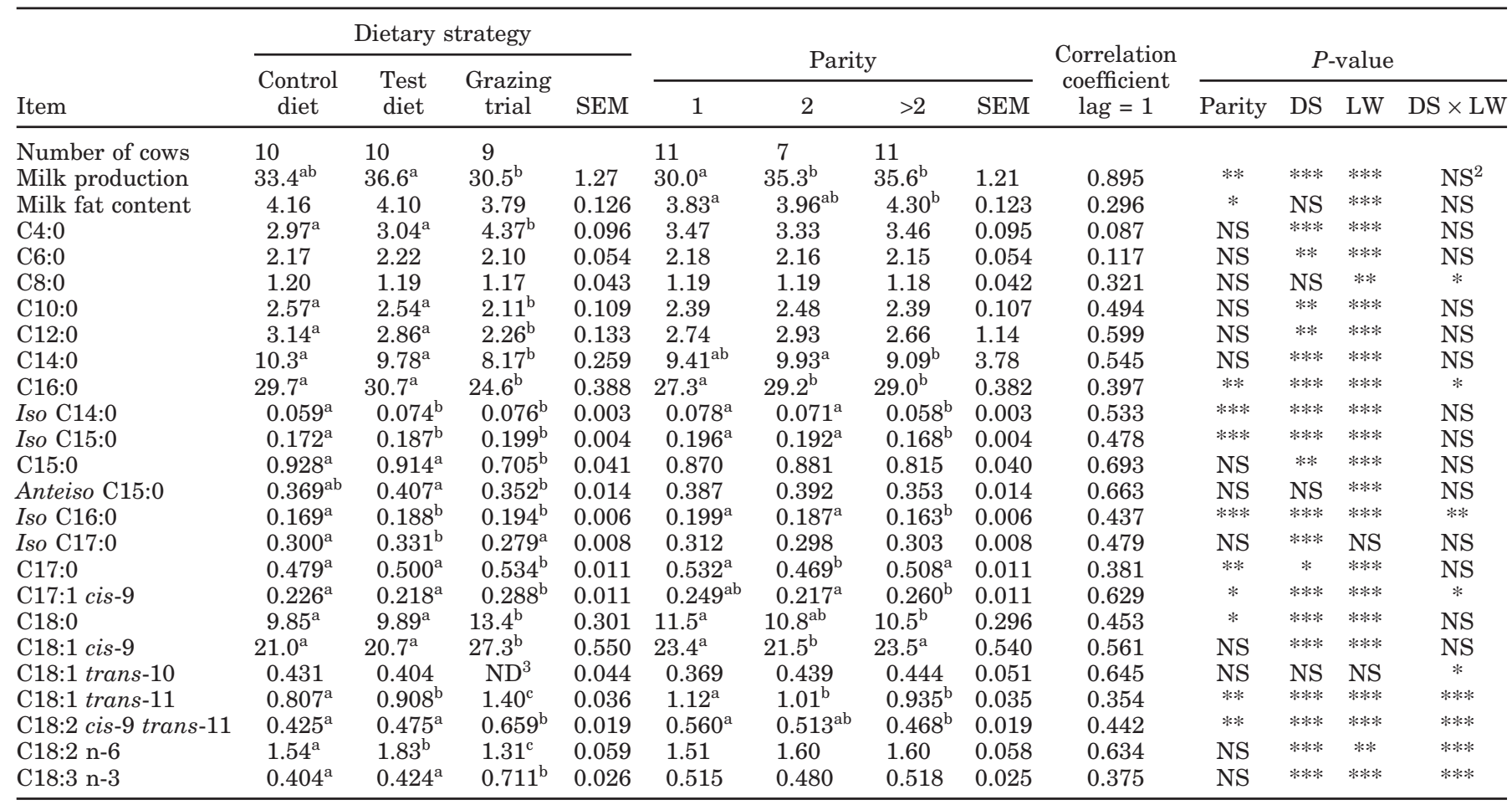

${ }^{a-c}$ Means of dietary strategies or parity groups within a row with different superscripts differ $(P<0.05)$.

${ }^{1}$ Observations were over a lactation period of $40 \mathrm{wk}$ for cows on the control or test dietary strategy in the stable trial and during the first $18 \mathrm{wk}$ of lactation for cows in the grazing trial. The estimated correlation coefficients between 2 measures on the same cow with a time interval of $1 \mathrm{wk}$ are included for the different variables.

${ }^{2}$ Not significant; $P>0.05$.

${ }^{3} \mathrm{ND}=$ not detectable

$* P<0.05 ; * * P<0.01 ; * * * P<0.001$.

this curve fitting to estimate average Wood functions per dietary strategy. For graphical presentation of the results, the calculated Wood functions were plotted against the least squares means of milk production, milk fat content, and individual milk FA estimated by the LMM. Coefficients of determination are calculated between these least squares means and the corresponding values predicted by the Wood functions.

Additionally, individual Wood functions were fit to individual animal data for the same dependent variables (milk production, milk fat content, and specific milk FA). The individual parameter estimates derived from these fittings were used to investigate relationships between milk production, milk fat content, and the specific milk FA by calculating Pearson correlation coefficients (Choumei et al., 2006). This allowed the evaluation of coinciding variation due to lactation stage in milk production, milk fat content, and individual milk FA.

Emphasis is put on the OBCFA, in accordance with the aim of this study. However, lactation curves were also fit to some other milk FA, which allowed comparison between OBCFA and milk FA for which the lactation effect has been described in literature.

Lactation curves of $\mathrm{C} 18$ biohydrogenation intermediates (C18:1 trans-10, C18:1 trans-11, C18:2 cis-9 trans-11, linoleic (C18:2 n-6) and linolenic acids (C18:3 $\mathrm{n}-3)$ are not described in this paper because of the strong effect of dietary strategies applied during the current experiments (e.g., introduction of extruded linseed in the grazing trial) as well as dietary strategies applied during the anabolic period of the previous lactation on these milk FA, which might have affected the accumulation of these FA in the adipose tissue. Nevertheless, dietary least squares means of these FA are reported. Over the studied lactation period, variation in the sum of these FA was limited (between 4.5 and $5.5 \mathrm{~g} / 100 \mathrm{~g}$ of total milk FA), ruling out a major contribution of these FA (e.g., through dilution).

The Wood function was not fit to C4:0 and C6:0 either, because of the deviating patterns compared with other short-chain FA. This might be related to the dual 
origin of C4:0, via acetyl coenzyme A dependent and independent pathways (Palmquist et al., 1993). Differences in C6:0 might be related to the fact that only 1 acetyl unit is required to be added via malonyl coenzyme A. The pattern of OBCFA as a function of lactation stage was compared with formerly described changes in SMCFA and LCFA (Palmquist et al., 1993).

\section{RESULTS}

\section{General Observations}

The stable-fed cows and in particular the cows receiving the test dietary strategy showed greater milk production compared with the grazing cows (36.6 vs. $30.5 \mathrm{~kg} / \mathrm{d}$ for the test and grazing dietary strategy, respectively; Table 3), which is also reflected in the parameter $a$ of the Wood function (Table 4). Figure 2 shows the average weekly milk production and milk fat content as a function of lactation week for the different dietary strategies as estimated by the LMM as well as the fitted Wood functions. For the 3 dietary strategies, the Wood functions of milk production showed an increasing and then gradually decreasing pattern (Figure 2), with relatively similar parameters $b$ and $c$ and peak production at wk 6 to 8 (Table 4).

Milk fat content showed a rapid decrease during the first weeks after calving, reaching a minimum at about wk 14 of lactation for the cows of the stable trial and at wk 10 of lactation for the grazing cows. Milk fat content in the first week after calving was similar for the different diets, but the grazing cows showed a stronger decrease during the early lactation period, as indicated by the greater parameter $b$ in grazing cows compared with the stable-fed cows. After the milk fat content reached a minimum value, a slight increase was observed for the cows in the stable trial. For the grazing trial these data were not available, because data were recorded during the first 18 wk of lactation only in this experiment. The estimated average milk fat content was not significantly different between the dietary strategies (Table 3).

Estimates of the average correlation as a function of lag are presented in Figure 3 and correlation coefficients of the first lactation week are given in Table 3. Milk production shows high correlation coefficients that decrease as lag time increases. Milk fat content shows lower correlation coefficients compared with milk production that decrease more rapidly with increasing lag time during early lactation. Milk fat content reaches constant correlation coefficients after a lag of $4 \mathrm{wk}$.

\section{Lactation Curves of Individual Milk FA}

Estimated average proportions of individual milk FA in milk fat (g/100 $\mathrm{g}$ of milk FA) for the different dietary strategies are shown in Table 3 . The parameters of the Wood function for the milk FA are given in Table 4. Figure 4 shows the Wood function and the average weekly proportions in milk fat of C14:0 as an example of the lactation curves of de novo synthesized SMCFA (C8:0 to C14:0), and of C18:1 cis-9, which is representative of LCFA. Lactation curves and the LMM estimates for the most relevant OBCFA are shown in Figure 5. Lactation week had a strong significant effect on milk FA proportions. Levels of milk FA differed between the dietary strategies, as shown by the averages per dietary strategy estimated by the LMM (Table 3) and parameter $a$ of the lactation curves (Table 4). This parameter gives an indication of the initial value of the milk FA in early lactation and is associated with the average level of milk FA during the rest of the lactation period.

The grazing cows showed lower proportions of all SMCFA in milk except C4:0 and greater proportions of $\mathrm{C} 4: 0$ and all C18 FA except C18:2 n-6 compared with cows of the stable trial. The cows receiving the control diet showed lower proportions of most iso FA (iso $\mathrm{C} 14: 0$, iso $\mathrm{C} 15: 0$, and iso C16:0) in milk fat compared with cows receiving the test dietary strategy or the grazing cows. Iso C17:0 was greater for the cows on the test diet. The grazing cows showed lower proportions of C15:0, and anteiso C15:0 proportions were found to be greater for cows receiving the test diet compared with the grazing cows.

Despite the different FA levels in milk fat when feeding different diets, as reflected in parameter $a$, similar shapes of lactation curves could be observed as reflected by the parameter $b$. The SMCFA increased during early lactation (Figure 4), which was in most cases completed after $10 \mathrm{wk}$ of lactation, reaching constant or slightly decreasing proportions. For all dietary strategies, parameter $b$ increased with FA chain length from 8 to 12 . Fatty acid C16:0 showed constant proportions throughout lactation, which is shown by the low parameter $b$ for C16:0 (Table 4). For this FA, curve fitting was inappropriate for the results of the grazing trial, as indicated by the very low $R^{2}$ values. Stearic acid and oleic acid decreased (Figure 4) during the first weeks of lactation. In the grazing experiment, the decrease of C18:1 cis-9 was more gradual and continued at the end of the registration (18 wk of lactation) resulting in a slightly deviating pattern compared with lactation curves of the stable trial.

For the OBCFA, iso C14:0, iso C15:0, C15:0, and anteiso C15:0 (Figure 5) followed the pattern of the 
Table 4. Parameter means ( $a, b$, and $c$ ) and their standard deviations (SD) as well as coefficients of determination of the incomplete $\gamma$-function of Wood for individual milk fatty acids (FA; $\mathrm{g} / 100 \mathrm{~g}$ of milk FA), milk production $(\mathrm{kg} / \mathrm{d})$, and milk fat content (g/100 $\mathrm{g}$ of milk) for the 3 dietary strategies $^{1}$

\begin{tabular}{|c|c|c|c|c|c|c|c|c|c|c|c|c|c|c|c|c|c|c|c|c|c|}
\hline \multirow[b]{4}{*}{ Item } & \multicolumn{14}{|c|}{ Stable trial } & & & & & & & \\
\hline & \multicolumn{7}{|c|}{ Control } & \multicolumn{7}{|c|}{ Test } & \multicolumn{7}{|c|}{ Grazing trial } \\
\hline & \multicolumn{2}{|c|}{$a$} & \multicolumn{2}{|c|}{$b$} & \multicolumn{2}{|c|}{$c$} & \multirow[b]{2}{*}{$\mathrm{R}^{2}$} & \multicolumn{2}{|c|}{$a$} & \multicolumn{2}{|c|}{$b$} & \multicolumn{2}{|c|}{$c$} & \multirow[b]{2}{*}{$\mathrm{R}^{2}$} & \multicolumn{2}{|c|}{$a$} & \multicolumn{2}{|c|}{$b$} & \multicolumn{2}{|c|}{$c$} & \multirow[b]{2}{*}{$\mathrm{R}^{2}$} \\
\hline & Mean & $\mathrm{SD}$ & Mean & SD & Mean & $\mathrm{SD}$ & & Mean & $\mathrm{SD}$ & Mean & SD & Mean & $\mathrm{SD}$ & & Mean & $\mathrm{SD}$ & Mean & SD & Mean & SD & \\
\hline Milk production & 30.7 & 1.64 & 0.196 & 0.039 & 0.027 & 0.003 & 0.965 & 33.0 & 1.57 & 0.175 & 0.036 & 0.022 & 0.003 & 0.973 & 28.4 & 1.28 & 0.154 & 0.051 & 0.026 & 0.008 & 0.848 \\
\hline Milk fat & 5.13 & 0.180 & -0.183 & 0.026 & -0.014 & 0.002 & 0.865 & 5.02 & 0.175 & -0.163 & 0.027 & -0.011 & 0.002 & 0.865 & 4.76 & 0.266 & -0.198 & 0.071 & -0.019 & 0.012 & 0.715 \\
\hline C8:0 & 1.21 & 0.102 & 0.086 & 0.063 & 0.014 & 0.005 & 0.479 & 1.05 & 0.075 & 0.095 & 0.052 & 0.006 & 0.004 & 0.256 & 0.865 & 0.048 & 0.163 & 0.057 & 0.001 & 0.080 & 0.915 \\
\hline C10:0 & 2.05 & 0.155 & 0.201 & 0.053 & 0.015 & 0.004 & 0.623 & 1.91 & 0.144 & 0.170 & 0.053 & 0.007 & 0.004 & 0.695 & 1.45 & 0.122 & 0.187 & 0.084 & -0.002 & 0.020 & 0.896 \\
\hline C12:0 & 2.13 & 0.153 & 0.243 & 0.049 & 0.011 & 0.004 & 0.831 & 1.95 & 0.131 & 0.208 & 0.046 & 0.006 & 0.003 & 0.873 & 1.67 & 0.192 & 0.324 & 0.121 & 0.037 & 0.012 & 0.583 \\
\hline C14:0 & 7.87 & 0.313 & 0.144 & 0.027 & 0.004 & 0.002 & 0.881 & 7.67 & 0.312 & 0.136 & 0.029 & 0.005 & 0.002 & 0.872 & 6.61 & 0.380 & 0.112 & 0.062 & 0.000 & 0.009 & 0.852 \\
\hline Iso C14:0 & 0.041 & 0.004 & 0.149 & 0.067 & -0.001 & 0.005 & 0.842 & 0.054 & 0.004 & 0.184 & 0.046 & 0.007 & 0.004 & 0.763 & 0.062 & 0.003 & 0.136 & 0.060 & 0.006 & 0.009 & 0.812 \\
\hline C15:0 & 0.725 & 0.056 & 0.145 & 0.053 & 0.005 & 0.004 & 0.828 & 0.711 & 0.036 & 0.135 & 0.036 & 0.004 & 0.003 & 0.858 & 0.554 & 0.039 & 0.166 & 0.073 & 0.009 & 0.011 & 0.856 \\
\hline Iso $\mathrm{C} 15: 0$ & 0.127 & 0.007 & 0.118 & 0.036 & -0.002 & 0.003 & 0.908 & 0.141 & 0.006 & 0.161 & 0.029 & 0.005 & 0.002 & 0.786 & 0.171 & 0.008 & 0.055 & 0.053 & -0.006 & 0.008 & 0.774 \\
\hline Anteiso C15:0 & 0.258 & 0.014 & 0.173 & 0.037 & 0.003 & 0.003 & 0.932 & 0.273 & 0.014 & 0.218 & 0.035 & 0.006 & 0.003 & 0.959 & 0.245 & 0.017 & 0.265 & 0.071 & 0.011 & 0.010 & 0.960 \\
\hline $\mathrm{C} 16: 0$ & 25.6 & 0.590 & 0.045 & 0.016 & 0.003 & 0.001 & 0.947 & 27.1 & 0.666 & 0.022 & 0.018 & -0.005 & 0.001 & 0.957 & 25.0 & 0.589 & -0.022 & 0.027 & -0.003 & 0.004 & 0.111 \\
\hline Iso $\mathrm{C} 16: 0$ & 0.145 & 0.010 & 0.003 & 0.049 & -0.010 & 0.004 & 0.809 & 0.160 & 0.007 & 0.077 & 0.033 & 0.001 & 0.003 & 0.784 & 0.177 & 0.010 & 0.212 & 0.061 & 0.037 & 0.010 & 0.775 \\
\hline C17:0 & 0.638 & 0.022 & -0.186 & 0.027 & -0.009 & 0.002 & 0.863 & 0.672 & 0.017 & -0.149 & 0.021 & -0.002 & 0.002 & 0.943 & 0.731 & 0.019 & -0.156 & 0.034 & -0.005 & 0.006 & 0.983 \\
\hline Iso C17:0 & 0.331 & 0.017 & -0.038 & 0.025 & -0.003 & 0.002 & 0.278 & 0.340 & 0.010 & -0.016 & 0.022 & -0.001 & 0.001 & 0.03 & 0.310 & 0.013 & -0.086 & 0.050 & -0.006 & 0.008 & 0.547 \\
\hline $\mathrm{C} 17: 1$ cis -9 & 0.340 & 0.017 & -0.218 & 0.042 & -0.004 & 0.004 & 0.856 & 0.321 & 0.020 & -0.177 & 0.053 & -0.004 & 0.005 & 0.677 & 0.454 & 0.017 & -0.040 & 0.055 & 0.051 & 0.011 & 0.962 \\
\hline C18:0 & 12.9 & 0.420 & -0.140 & 0.026 & -0.002 & 0.002 & 0.957 & 12.3 & 0.404 & -0.041 & 0.027 & 0.011 & 0.003 & 0.95 & 14.5 & 0.524 & -0.063 & 0.043 & -0.004 & 0.007 & 0.396 \\
\hline C18:1 cis-9 & 25.7 & 0.797 & -0.114 & 0.024 & -0.003 & 0.002 & 0.827 & 25.4 & 0.910 & -0.096 & 0.029 & 0.000 & 0.003 & 0.822 & 31.0 & 0.883 & -0.021 & 0.035 & 0.011 & 0.006 & 0.864 \\
\hline
\end{tabular}

${ }^{1}$ Observations were over a lactation period of $40 \mathrm{wk}$ for cows on the control $(\mathrm{n}=10)$ or test $(\mathrm{n}=10)$ dietary strategy in the stable trial and during the first $18 \mathrm{wk}$ of lactation for cows of the grazing trial $(n=9)$. 

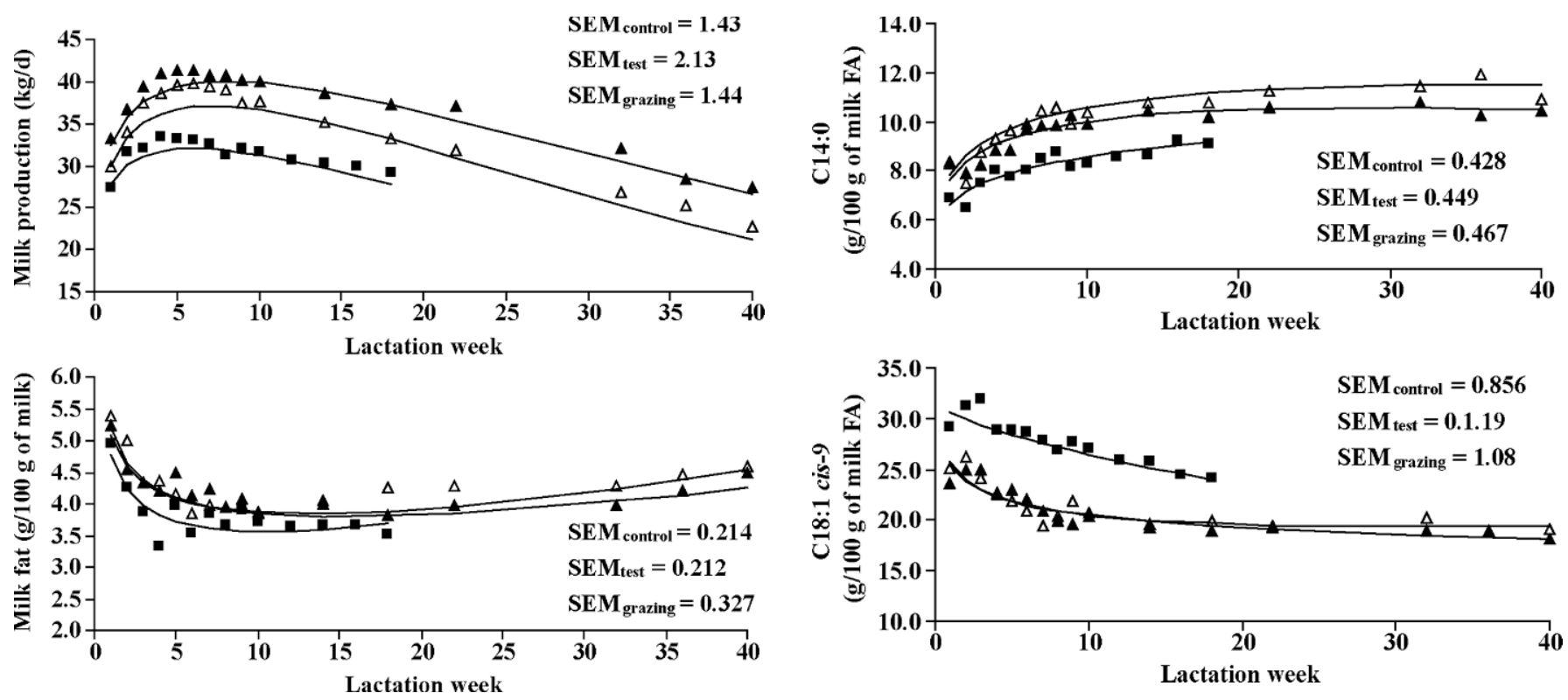

Figure 2. Milk production (kg/d) and milk fat content $(\mathrm{g} / 100 \mathrm{~g}$ of milk) as a function of lactation week for the cows receiving the control $(\triangle$ : lactation wk 1 to $40, \mathrm{n}=10)$ or the test dietary strategy ( $\mathbf{\Delta}$ : lactation wk 1 to $40, \mathrm{n}=10$ ) during the stable trial or involved in the grazing trial ( $\mathbf{\square}$ : lactation wk 1 to $18, \mathrm{n}=9$ ). SEM refers to standard error of the mean; when data were missing, SEM was calculated as the weighted average of the SEM values.

SMCFA (Figure 4). These milk FA increased during early lactation, until they reached constant proportions after 10 to 16 wk of lactation. Parameter $b$ of the Wood functions of individual milk FA were similar for

the different dietary strategies, except for iso C15:0, which was much lower for the grazing experiment and anteiso $\mathrm{C} 15$ :0, which was greater for the grazing experiment. This was caused by 3 and 1 cow(s), respectively,

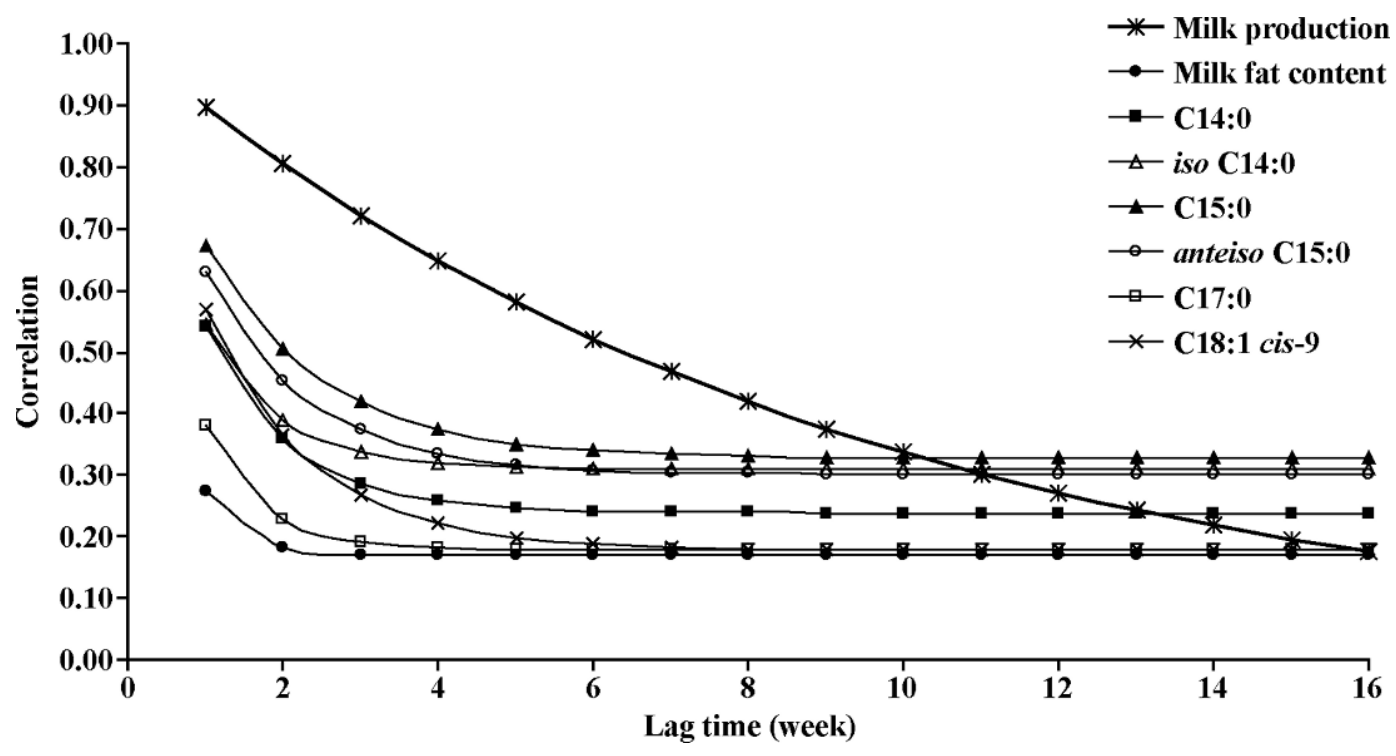

Figure 3. Estimated correlation functions from autoregressive plus random effect covariance structures for milk production (kg/d), milk fat content ( $\mathrm{g} / 100 \mathrm{~g}$ of milk), and some individual milk fatty acids ( $\mathrm{g} / 100 \mathrm{~g}$ of milk fatty acids). 

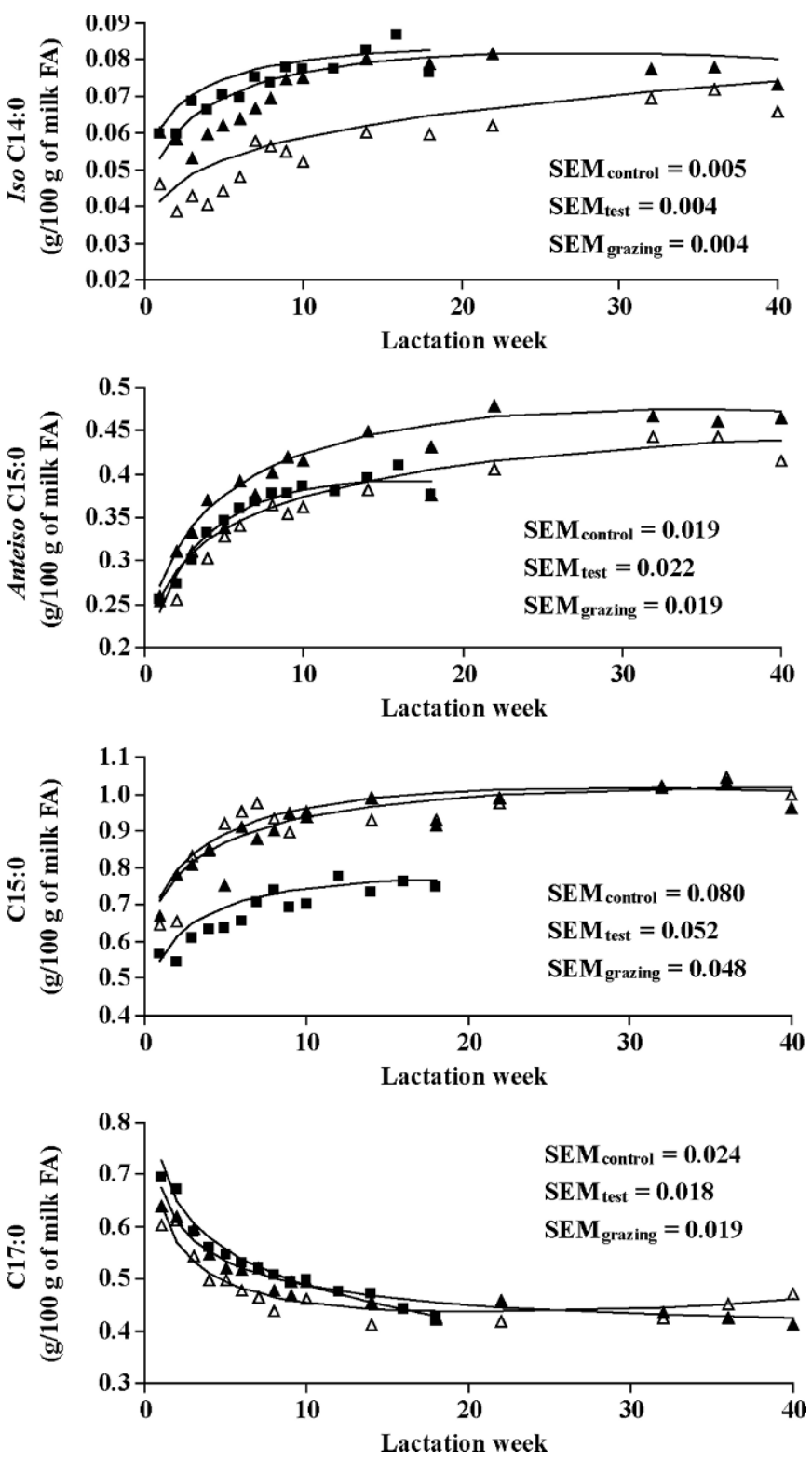

Figure 5. Fatty acids (FA) iso C14:0, C15:0, anteiso C15:0, and $\mathrm{C} 17: 0(\mathrm{~g} / 100 \mathrm{~g}$ of milk FA) as a function of lactation week for the cows receiving the control $(\triangle$ : lactation wk 1 to $40, \mathrm{n}=10)$ or the test dietary strategy ( $\mathbf{\Lambda}$ : lactation wk 1 to $40, \mathrm{n}=10$ ) during the stable trial or involved in the grazing trial (ष: lactation wk 1 to 18 , $\mathrm{n}=9$ ). SEM refers to standard error of the mean; when data were missing, SEM was calculated as the weighted average of the SEM values.

that deviated from the average pattern. Elimination of these data from the curve-fitting database generated slopes that were closer to those of the stable trial. Apparently, and for unknown reasons, the impact of animal variation among animals was stronger for these 2 OBCFA.

Fatty acids C17:0 and C17:1 cis-9 decreased during the first weeks of lactation and therefore followed the pattern of the LCFA. iso C17:0 showed constant lactation curves, which is reflected in the low value of the parameters $b$ and the low coefficients of determination of the Wood functions of this FA.

During the first 2 wk of lactation, milk FA fluctuated strongly, with the typical increasing or decreasing part of the Wood function starting mostly at the third week of lactation only. For example, C14:0 decreased slightly from wk 1 to 2 of lactation and started to increase during the third week of lactation for the different diets. Proportions of iso C14:0 decreased slightly during the first $3 \mathrm{wk}$ of lactation for the stablefed cows and started to increase from wk 4 of lactation. iso C14:0 proportions in the milk fat of grazing cows did not show any variation during the first 2 wk of lactation. Fatty acid C18:1 cis-9 increased during wk 1 and 2 of lactation and showed its typical decreasing pattern thereafter. Fatty acid C18:1 cis-9 in particular showed a strong increase for cows from the grazing trial during the second week of lactation. Although C18:1 cis-9 decreased from the third week of lactation, this fluctuation in the first $2 \mathrm{wk}$ of lactation increased the average parameter $b$ for the grazing cows compared with the cows of the stable trial.

Parameter $c$ is not discussed in detail, because in the grazing experiment the cows were monitored during the first 18 wk of lactation only, which could have hampered the estimation of the parameter $c$. Moreover, milk FA showed low values for parameter $c$, which is caused by the relatively stable pattern in mid and late lactation. The main changes in milk FA occurred during the first 10 wk of lactation, which is different from the lactation curves of milk production, which showed a decrease after peak production, or milk fat content, which increased after the minimum. Hence, in the case of individual milk FA concentrations, the ratio $b / c$, generally appropriate to calculate the time at peak or minimum, resulted in aberrant values and thus, the lactation week after which milk FA reached constant proportions was determined visually.

The correlation coefficients of the covariance structures of the milk FA decreased with increasing lag time (Figure 3). Milk FA proportions in consecutive milk samples (1-wk interval) within one animal showed lower correlations compared with milk production (Table 3). Among the different milk FA, no major differences in covariance structure were observed. The covariance structure of the milk FA showed a greater similarity with the milk fat content compared with milk production.

\section{Relationship Between Individual Milk FA, Milk Production, and Milk Fat Content}

Overall, average changes during lactation in proportions of individual milk FA were consistent for the 
Table 5. Pearson correlations between starting value (parameter $a$ of the incomplete $\gamma$-function of Wood) of milk production $(\mathrm{kg} / \mathrm{d})$ and milk fat $(\mathrm{g} / 100 \mathrm{~g}$ of milk) and the starting value and slope until maximum, minimum, or constant values (parameter $b$ of the incomplete $\gamma$-function of Wood) of milk fatty acid (FA) proportions ( $\mathrm{g} / 100 \mathrm{~g}$ of milk FA) for the 3 dietary strategies ${ }^{1}$

\begin{tabular}{|c|c|c|c|c|c|c|}
\hline \multirow[b]{2}{*}{ Fatty acid } & \multicolumn{3}{|c|}{$a$, milk production } & \multicolumn{3}{|c|}{$a$, milk fat } \\
\hline & Control diet & Test diet & Grazing trial & Control diet & Test diet & Grazing trial \\
\hline \multicolumn{7}{|l|}{$a$ parameter } \\
\hline C10:0 & -0.25 & -0.33 & -0.04 & -0.38 & -0.61 & 0.03 \\
\hline C12:0 & $-0.78^{*}$ & -0.27 & 0 & $-0.76^{*}$ & $-0.70 *$ & 0 \\
\hline C14:0 & $-0.75^{*}$ & -0.1 & -0.17 & $-0.77^{*}$ & -0.55 & 0.13 \\
\hline C16:0 & -0.03 & 0.19 & -0.46 & -0.06 & 0.03 & 0.46 \\
\hline Iso C14:0 & $-0.76^{*}$ & -0.61 & -0.06 & -0.56 & -0.46 & -0.61 \\
\hline Iso C15:0 & $-0.89 * *$ & $-0.66^{*}$ & -0.17 & $-0.73^{*}$ & -0.27 & -0.65 \\
\hline C15:0 & $-0.91 * *$ & -0.41 & -0.21 & $-0.88 * *$ & $-0.74 *$ & -0.59 \\
\hline Anteiso C15:0 & $-0.85^{*}$ & -0.38 & 0.2 & $-0.80 *$ & $-0.69 *$ & -0.59 \\
\hline Iso $\mathrm{C} 17: 0$ & 0.02 & 0.27 & 0.13 & -0.002 & 0.36 & -0.57 \\
\hline C17:0 & 0.22 & 0.06 & -0.39 & 0.15 & $0.80^{* *}$ & -0.31 \\
\hline C18:0 & 0.29 & -0.24 & -0.23 & 0.35 & -0.02 & -0.54 \\
\hline C18:1 cis -9 & 0.66 & 0.23 & 0.38 & 0.52 & 0.54 & -0.09 \\
\hline Milk production & & & & 0.72 & 0.38 & 0.18 \\
\hline \multicolumn{7}{|l|}{$b$ parameter } \\
\hline C10:0 & 0.29 & 0.31 & 0.21 & 0.39 & $0.66^{*}$ & -10.47 \\
\hline $\mathrm{C} 12: 0$ & 0.62 & 0.3 & 0.2 & 0.64 & 0.59 & -0.37 \\
\hline C14:0 & 0.6 & 0.02 & 0.37 & $0.67 *$ & 0.3 & -0.59 \\
\hline C16:0 & 0.16 & 0.11 & 0.64 & 0.1 & -0.46 & -0.54 \\
\hline Iso C14:0 & 0.33 & 0.08 & 0.42 & 0 & 0.47 & -0.02 \\
\hline Iso C15:0 & $0.82 * *$ & 0.02 & 0.42 & 0.54 & -0.11 & 0.03 \\
\hline C15:0 & 0.58 & 0.5 & 0.41 & $0.86 * *$ & $0.70 *$ & -0.1 \\
\hline Anteiso C15:0 & 0.66 & 0.04 & 0.17 & $0.79 *$ & 0.27 & 0.08 \\
\hline Iso $\mathrm{C} 17: 0$ & -0.24 & -0.41 & 0.22 & -0.25 & -0.17 & 0.43 \\
\hline C17:0 & -0.18 & 0.06 & 0.09 & -0.14 & -0.47 & 0.43 \\
\hline C18:0 & -0.38 & -0.17 & 0.09 & -0.54 & 0.35 & 0.29 \\
\hline C18:1 cis-9 & $-0.68^{*}$ & -0.24 & -0.44 & -0.62 & -0.04 & 0.6 \\
\hline Milk production & & & & 0.04 & -0.23 & 0.27 \\
\hline
\end{tabular}

${ }^{1}$ Observations were over a lactation period of $40 \mathrm{wk}$ for cows on the control $(\mathrm{n}=10)$ or test $(\mathrm{n}=10)$ dietary strategy in the stable trial and during the first $18 \mathrm{wk}$ of lactation for cows of the grazing trial $(\mathrm{n}=9)$.

$* P<0.05 ; * * P<0.01 ; * * * P<0.001$.

different dietary strategies. However, as already highlight for some milk FA (e.g., iso $\mathrm{C} 15: 0$ and anteiso C15:0), animal variability was not negligible. This might significantly affect the parameter estimates of the Wood function when fitting the curve to individual animal data. We investigated whether similar animal variation is observed in milk FA Wood parameters and parameters of easy-to-measure animal characteristics such as milk production or milk fat content. To assess the concomitant variation in milk FA proportions, milk fat content and milk production, correlations coefficients were calculated between the $a$ and $b$ parameters of their Wood functions. The correlation coefficients with the slope after the minimum or maximum (parameter $c$ ) were not considered because milk FA seemed to change mainly during the early lactation period.

Tables 5 and 6 list the Pearson correlation coefficients between the Wood parameters of milk production, milk fat content, and milk FA proportions. Correlation coefficients were mostly very low, particularly for the grazing trial. This is probably due to the more practical, and therefore more variable, conditions of the grazing experiment compared with the stable experiment. The cows receiving the control dietary strategy in the stable trial showed the greatest and most significant correlation coefficients.

Significant negative correlations were found between initial proportions in milk fat of $\mathrm{C} 12: 0, \mathrm{C} 14: 0$, iso $\mathrm{C} 14: 0$, iso $\mathrm{C} 15: 0, \mathrm{C} 15: 0$, and anteiso $\mathrm{C} 15: 0$, and the initial milk production and milk fat content for the cows receiving the control diet in the stable trial. This implies that cows with a greater milk production or greater milk fat content at the onset of the lactation seem to be characterized by lower initial proportions in milk fat of SMCFA and OBCFA, with a maximum chain length of 15 carbon atoms. Greater initial milk production or milk fat at the start of the lactation (parameter $a$ ) tends to lead to a stronger, although not always significant, increase (parameter $b$ ) of the SMCFA and short OBCFA. However, correlations between parameters $a$ and $b$ should be interpreted with caution. Indeed, because of the curve-fitting procedure 
Table 6. Pearson correlation between slope until maximum or minimum (parameter $b$ of the incomplete $\gamma$ function of Wood) of milk production $(\mathrm{kg} / \mathrm{d})$ and milk fat $(\mathrm{g} / 100 \mathrm{~g}$ of milk) and the starting value (parameter $a$ of the incomplete $\gamma$-function of Wood) and slope until maximum, minimum, or constant values of milk fatty acid (FA) proportions ( $\mathrm{g} / 100 \mathrm{~g}$ of milk FA) for the 3 dietary strategies ${ }^{1}$

\begin{tabular}{|c|c|c|c|c|c|c|}
\hline \multirow[b]{2}{*}{ Fatty acid } & \multicolumn{3}{|c|}{$b$, milk production } & \multicolumn{3}{|c|}{$b$, milk fat } \\
\hline & Control diet & Test diet & Grazing trial & Control diet & Test diet & Grazing trial \\
\hline$a$ parameter & -0.33 & -0.09 & -0.45 & 0.5 & 0.53 & 0.21 \\
\hline C10:0 & 0.02 & -0.17 & -0.27 & 0.58 & 0.63 & 0.24 \\
\hline C12:0 & 0.09 & -0.01 & -0.35 & 0.6 & 0.47 & 0.13 \\
\hline C14:0 & 0.46 & 0.23 & 0.12 & 0.08 & 0 & -0.06 \\
\hline $\mathrm{C} 16: 0$ & 0.01 & -0.03 & $-0.68^{*}$ & 0.28 & 0.47 & 0.48 \\
\hline Iso C14:0 & 0.14 & -0.09 & -0.49 & 0.3 & 0.11 & 0.62 \\
\hline Iso C15:0 & 0.14 & -0.18 & $-0.75^{*}$ & 0.45 & $0.71 *$ & 0.27 \\
\hline C15:0 & 0.14 & -0.27 & -0.6 & 0.4 & 0.55 & 0.48 \\
\hline Anteiso C15:0 & -0.37 & -0.48 & 0.21 & 0.18 & -0.48 & 0.64 \\
\hline Iso $\mathrm{C} 17: 0$ & -0.03 & -0.4 & 0.04 & -0.44 & -0.37 & 0.04 \\
\hline $\mathrm{C} 17: 0$ & 0.04 & 0.4 & -0.53 & -0.63 & -0.04 & 0.17 \\
\hline C18:0 & -0.14 & -0.02 & 0.41 & -0.48 & -0.42 & -0.17 \\
\hline C18:1 cis-9 & -0.28 & -0.05 & -0.34 & -0.17 & -0.22 & -0.27 \\
\hline Milk production & & & & $-0.68^{*}$ & $-0.64^{*}$ & $-0.76^{*}$ \\
\hline \multicolumn{7}{|l|}{$b$ parameter } \\
\hline $\mathrm{C} 10: 0$ & 0.14 & -0.21 & -0.11 & -0.54 & -0.31 & -0.01 \\
\hline C12:0 & -0.03 & 0.19 & -0.43 & -0.6 & -0.27 & -0.12 \\
\hline C14:0 & -0.05 & 0.05 & -0.32 & -0.62 & -0.04 & 0.09 \\
\hline C16:0 & -0.62 & 0.26 & $-0.70^{*}$ & 0.25 & 0.5 & 0.22 \\
\hline Iso C14:0 & -0.34 & -0.07 & 0.2 & 0.11 & -0.43 & -0.26 \\
\hline Iso $\mathrm{C} 15: 0$ & -0.03 & 0.37 & -0.12 & -0.27 & 0.19 & -0.53 \\
\hline C15:0 & 0.13 & 0.28 & -0.41 & $-0.67^{*}$ & -0.61 & -0.5 \\
\hline Anteiso C15:0 & 0.25 & $0.66^{*}$ & -0.2 & $-0.70 *$ & -0.38 & $-0.67^{*}$ \\
\hline Iso C17:0 & $0.73^{*}$ & 0.4 & -0.48 & 0.11 & 0.09 & -0.59 \\
\hline C17:0 & -0.06 & 0.13 & 0.12 & 0.51 & -0.01 & -0.16 \\
\hline C18:0 & -0.09 & -0.18 & $0.76^{*}$ & $0.72 *$ & -0.52 & 0.15 \\
\hline C18:1 cis-9 & -0.02 & -0.15 & 0.35 & 0.57 & -0.37 & -0.14 \\
\hline Milk production & & & & -0.53 & -0.26 & -0.04 \\
\hline
\end{tabular}

${ }^{1}$ Observations were over a lactation period of $40 \mathrm{wk}$ for cows on the control $(\mathrm{n}=10)$ or test $(\mathrm{n}=10)$ dietary strategy in the stable trial and during the first $18 \mathrm{wk}$ of lactation for cows of the grazing trial $(\mathrm{n}=9)$.

$* P<0.05 ; * * P<0.01 ; * * * P<0.001$

they cannot be considered mathematically independent.

\section{DISCUSSION}

Average changes in FA proportions in milk fat were well described by the Wood function, as indicated by their high coefficients of determination (Table 4). The dietary strategy had a significant effect on milk production and milk FA proportions, which is also reflected by parameter $a$ of the Wood function (Table 4).

The interaction term (dietary strategy $\times$ lactation week) did not significantly affect milk production, milk fat content, or milk FA (except for the FA whose lactation curves are not reported for reasons stated earlier). Hence, similar shapes of lactation curves were expected for the 3 dietary strategies, which was confirmed for most of the FA as reflected by a similar parameter $b$ estimate for the different dietary strategies.

The grazing cows showed lower proportions of SMCFA and greater proportions of LCFA compared with the stable-fed cows, which can be explained by the greater supply of dietary linoleic and linolenic acids from the pasture (e.g., Elgersma et al., 2006; Ferlay et al., 2006). Dietary polyunsaturated FA and their biohydrogenation intermediates have a negative effect on de novo synthesis of SMCFA (Grummer, 1991; Palmquist et al., 1993; Barber et al., 1997; Chilliard et al., 2003), resulting in lower SMCFA proportions for grazing cows. It is suggested from the literature that these LCFA are potential inhibitors of mammary synthesis of FA with 10 to 14 carbon atoms through a direct inhibitory effect on the acetyl-CoA carboxylase activity (Barber et al., 1997; Chilliard et al., 2000; Ferlay et al., 2006).

The branched-chain milk FA (iso C14:0, iso C15:0, and iso C16:0), mainly originating from cellulolytic bacteria (Vlaeminck et al., 2006b), were lower for cows receiving the control dietary strategy, possibly as a result of the corn silage in the forage mixture and the lower content of crude fiber in this diet. The grazing cows and the stable-fed cows on the test diet showed similar proportions. The stable-fed cows showed 
Table 7. Pearson correlation between the slopes until maximum or minimum (parameter $b$ of the incomplete $\gamma$-function of Wood) of lactation curves fitted to milk C14:0, odd- and branched-chain fatty acid, and long-chain fatty acid proportions of individual cows over a lactation period of $40 \mathrm{wk}$ for cows on the control $(\mathrm{n}=10)$ or test $(\mathrm{n}=$ 10) dietary strategy in the stable trial and during the first $18 \mathrm{wk}$ of lactation for cows of the grazing trial $(n=9)$

\begin{tabular}{lccc}
\hline & \multicolumn{2}{c}{ C14:0; stable trial } & \\
\cline { 2 - 3 } Fatty acid & Control diet & Test diet & $\begin{array}{c}\text { C14:0; } \\
\text { grazing trial }\end{array}$ \\
\hline Iso C14:0 & -0.07 & 0.48 & 0.64 \\
Iso C15:0 & $0.72^{*}$ & 0.54 & $0.71^{*}$ \\
C15:0 & $0.72^{*}$ & 0.31 & $0.79^{*}$ \\
Anteiso C15:0 & $0.84^{* *}$ & 0.49 & 0.56 \\
Iso C17:0 & -0.52 & -0.49 & -0.12 \\
C17:0 & $-0.67^{*}$ & $-0.85^{* *}$ & -0.43 \\
C18:0 & $-0.81^{* *}$ & -0.52 & -0.37 \\
C18:1 cis-9 & $-0.94^{* *}$ & -0.55 & $-0.94^{* *}$ \\
\hline
\end{tabular}

$* P<0.05 ; * * P<0.01 ; * * * P<0.001$.

greater proportions of $\mathrm{C} 15: 0$, a fatty acid enriched in amylolytic bacteria (Vlaeminck et al., 2006b). iso C17:0 was greatest for the cows on the test diet, which could be related to the lower $\mathrm{CP}$ content in the compound feed (Cabrita et al., 2003). Because the experiments were running on 2 farms, the current experimental design did not allow us to completely separate dietary effects from management factors and genetic background. Hence, the factor "dietary strategy" of the statistical model also included the effect of management differences and the genetic background of the cows. Nevertheless, the differences between the average proportions of the milk FA for the 3 groups were mainly determined by dietary strategy because shifts were in accordance with the literature describing dietary effects on proportions of specific milk FA, as suggested earlier. Although levels of milk FA in milk fat differed between the different dietary strategies, the shapes of their lactation curves were rather similar. The lactation curves of the SMCFA and LCFA are in accordance with literature (Palmquist et al., 1993; Kay et al., 2005; Garnsworthy et al., 2006; van Knegsel et al., 2007). The increasing proportions of the SMCFA coincided with decreasing proportions of the LCFA because of inhibitory or dilution effects of LCFA on de novo synthesis of SMCFA in the mammary gland. This inverse relationship is also shown by a negative correlation coefficient between the parameter $b$ of the Wood functions of $\mathrm{C} 18: 0$ and $\mathrm{C} 18: 1 \mathrm{cis}-9$ on the one hand and C14:0 on the other hand (Table 7). Palmquist et al. (1993) observed increasing proportions of SMCFA in early lactation that reached maximal proportions at 8 wk of lactation. This increase coincides with the decreasing release of LCFA by adipose tissue mobilization, which is largely completed after 4 to $6 \mathrm{wk}$ of lactation. Parameter $b$ increased with increasing chain length from C8:0 to C12:0, but was lower for C14:0. This is in agreement with Palmquist et al. (1993), who reported that the synthesis of SMCFA is inhibited to different extents depending on chain length, with increasing inhibition from $\mathrm{C} 6$ to $\mathrm{C} 12$. The increasing inhibition with increasing chain length is consistent with condensation of acetyl units with a preformed 4carbon primer. Formation of $\mathrm{C} 6: 0$, requiring only one acetyl unit addition via malonyl-CoA, would be influenced less than longer chains, which require increasing numbers of acetyl unit additions (Palmquist et al., 1993). Alternatively, a lower supply of SMCFA precursors (acetate and butyrate) is suggested to provoke a decrease of milk SMCFA (Chilliard et al., 2000), although the literature is not unanimous on this precursor-product relation (e.g., Bauman and Griinari, 2003). During the early lactation period, a decrease in the rumen acetate to propionate ratio might have been expected due to increased intake of the compound feed. However, the latter was accompanied by an increase in total dry matter intake, which might have stimulated total rumen SCFA production, resulting in an equal or greater absolute supply of rumen acetate. Hence, it is unlikely that the lower milk SMCFA concentration in early lactation was provoked by an acetate deficiency.

The constant proportions of $\mathrm{C} 16: 0$ might be related to the multiple origins of this FA. It is partly de novo synthesized in the mammary gland and would therefore show an increasing slope in early lactation in line with the other SMCFA. However, C16:0 is also released by mobilization of body fat when cows are in negative energy balance, which would result in a decreasing slope of $\mathrm{C} 16: 0$ in the early lactation stage, similar to LCFA.

Compared with that in stable-fed cows, the proportion of $\mathrm{C} 18: 1 \mathrm{cis}-9$ in the milk of grazing cows decreased less during the first weeks of lactation as indicated by the lower value of parameter $b$. However, comparison of the pattern of this FA between the grazing and stable trials is impaired by high fluctuations in this milk FA during the first 2 wk of lactation for the grazing cows, which resulted in positive $b$ values for 5 of the 9 grazing cows. Introduction of extruded linseed during the early lactation period (lactation wk 5 to 10) increased the supply of polyunsaturated fatty acids for the grazing cows, which could have influenced the shape of the lactation curves of the LCFA and might explain the more gradual decrease of these milk FA for the grazing cows compared with the stable-fed cows.

The shapes of the lactation curves of OBCFA were similar for the 3 dietary strategies. Based on the slope until the minimum, peak, or constant value (parameter $b$ ), 2 groups of OBCFA could be distinguished. The 
first group included iso C14:0, iso C15:0, C15:0, and anteiso C15:0, which followed the increasing pattern of the SMCFA in early lactation and reached constant proportions after $12 \mathrm{wk}$ of lactation, which is also indicated by a positive correlation coefficient between the parameters $b$ of the lactation curves of these milk FA and this of C14:0 (Table 7). The second group includes C17:0 and C17:1 cis-9, which decreased in the early lactation and therefore followed the LCFA. Parameter $b$ of these milk FA showed a negative correlation with parameter $b$ of C14:0 (Table 7). This difference in pattern between $\mathrm{C} 17 \mathrm{FA}$ and the other OBCFA might be surprising because OBCFA are mainly produced by the bacterial population in the rumen (Vlaeminck et al., 2006b). In this respect bacterial growth, particularly of amylolytic bacteria, is expected to increase during the first weeks of lactation as the intake of the compound feed increased. However, indicators of amylolytic bacteria (C15:0) as well as cellulolytic bacteria (e.g., iso C14:0, iso C15:0, and anteiso C15:0) showed a similar increase during early lactation, whereas another linear odd-chain milk FA, C17:0, which is mainly produced by amylolytic bacteria, showed an opposite lactation curve compared with milk fat proportions of C15:0. As for SMCFA, increasing proportions of OBCFA with chain length of 14 and 15 carbon atoms during the first 16 wk of lactation might be the result of a dilution effect through FA supply from body reserve mobilization or of reduced de novo synthesis in the mammary gland because of a lack of precursor supply or an inhibitory effect of LCFA on de novo synthesis. The latter implies the availability in the mammary gland of precursors for the synthesis of OBCFA with a chain length of 14 to 15 carbon atoms. Earlier studies have shown that the linear odd-chain fatty acids (C15:0 and C17:0) can be synthesized de novo from propionate in adipose tissue and mammary gland of ruminants (Massart-Leën et al., 1983). The contribution of de novo synthesis to total concentrations in milk fat seems greater for C15:0 than C17:0 (Rigout et al., 2003), suggesting a limited ability to elongate C15:0 to C17:0 (Cabrita et al., 2007). Incorporation of methylmalonyl-CoA, a carboxylation product of propionate, at the first step of chain elongation would result in anteiso FA (Horning et al., 1961; Smith, 1994). Less information is available on the ability of the mammary gland to use isovalerylCoA, 2-methylbutyryl-CoA, and isobutyryl-CoA as primers for de novo FA synthesis of iso FA. Based on their ${ }^{14} \mathrm{C}$-isovaleric acid incorporation studies, Verbeke et al. (1959) suggested that de novo synthesis of $i s o$ branched-chain FA was limited. This has also been suggested by Vlaeminck et al. (2006b) based on duodenal flows and milk secretions, which did not differ for these branched-chain FA. Despite differences in affinity for de novo synthesis, similar shapes of lactation curves were observed for all OBCFA with chain lengths of 14 to 15 carbon atoms. This might suggest that the lower proportions of SMCFA and OBCFA with chain lengths of 14 to 15 carbon atoms in early lactation are the result of a dilution effect through increased supply of mobilized LCFA rather than an inhibitory effect of these LCFA on de novo synthesis.

Similar shapes of the lactation curves of LCFA and OBCFA with a chain length of 17 carbon atoms suggest a nonnegligible release of these odd-chain FA during mobilization of the adipose tissue. This implies preferential incorporation during anabolism of OBCFA with a chain length of 17 carbon atoms compared with OBCFA with chain lengths of 14 to 15 carbon atoms. Indeed, the ratio $\mathrm{C} 17: 0$ to $\mathrm{C} 15: 0$ in adipose tissue of sheep (Lourenço et al., 2007a,b) and beef (Raes et al., 2004) is approximately $2: 1$ to $3: 1$, whereas this ratio in milk fat is approximately $1: 2$. Hence, during the first weeks of lactation when the cow is mobilizing body fat, greater amounts of OBCFA with chain length of $\mathrm{C} 17$ carbon atoms will be released, leading to a similar lactation curve as for LCFA.

The low value for parameter $c$ indicates that milk FA show a stable pattern in mid and late lactation. The milk FA change mainly during the first $10 \mathrm{wk}$ of lactation, which implies that parameter $c$ could be removed from the Wood function. In that manner, only 2 parameters have to be estimated: the starting FA proportion and the slope during the first weeks of lactation until a constant maximum or minimum proportion is reached.

The correlation coefficients of the covariance structures give a measure of the correlation between 2 measures on the same cow, whereby observations close in time are more correlated than measures far apart in time. The decreasing correlation coefficients indicate that the AR(1) plus random effect structure was a good choice for modeling the covariance structure.

From the graph in Figure 3 it is clear that observations with an interval of $4 \mathrm{wk}$ or less are correlated with each other within a cow. This variation is not explained by the repeated-measure lactation week and might be referred to as phenotypic variation. This variation might originate from genetic effects or different responses of cows to the experimental conditions. The remaining correlation ( $>4 \mathrm{wk}$ interval) is due to coweffect only [inter-animal variance; $\sigma_{\text {animal }}^{2} /\left(\sigma_{\text {animal }}^{2}+\right.$ $\left.\sigma_{\text {residual }}^{2}\right)$ and can be related to, for example, genetic effects. Milk production clearly showed a different covariance pattern compared with the milk fat and the milk FA. For milk fat content and milk FA proportions, these correlation coefficients varied between 20 and 
$50 \%$, indicating that 20 to $50 \%$ of the random error of the statistical model can be explained by specific differences between cows.

The effect of lactation stage will be important for the adaptation of current prediction and classification models, based on milk OBCFA (Van Nespen et al., 2005; Vlaeminck et al., 2006a; Craninx et al., 2008). Appropriate performance of these prediction and classification models should be guaranteed during different lactation stages. Extensions to these models are needed regarding lactation stage. Despite animal variability, extensions aiming at introducing the currently observed effect of lactation stage will likely be based on overall average changes in milk FA concentrations, as the Wood function allowed a mathematical and accurate description of these changes. Nevertheless, it might be worthwhile to get further insight into factors determining animal variability because a significant part of the remaining random error is related to differences between cows. However, based on the correlation coefficients between the Wood function parameters for milk FA on the one hand and milk production or milk fat content on the other hand, the latter 2 easy-tomeasure variables show limited potential to quantify animal variability.

\section{CONCLUSIONS}

From this study, it can be concluded that lactation stage influences proportions of SMCFA and LCFA as well as OBCFA in milk fat. The incomplete lactation curve of Wood appropriately models changes in milk FA proportions observed mainly during the early lactation period. Although dietary conditions determined milk FA proportions, the shape of the milk FA lactation curves was independent of dietary strategy. Short- and medium-chain FA and OBCFA with chain lengths of 14 or 15 carbon atoms showed an increasing pattern during the early lactation period, whereas LCFA and OBCFA with chain lengths of 17 carbon atoms decreased. The latter discrepancy is thought to be caused by a dilution effect and possibly an inhibition effect by LCFA rather than by their production in the rumen.

\section{ACKNOWLEDGMENTS}

The authors would like to acknowledge the IWT (Institute for the Promotion of Innovation by Science and Technology, Flanders Belgium) for their financial support. Charlotte Melis, Sjarai Deschildre, Sven De Donder, and Mario Willen (LANUPRO, Ghent University, Melle, Belgium) are acknowledged for technical assistance.

\section{REFERENCES}

Barber, M. C., R. A. Clegg, M. T. Travers, and R. G. Vernon. 1997. Lipid mechanism in the lactating mammary gland. Biochim. Biophys. Acta 1347:101-126.

Bauman, D. E., and J. M. Griinari. 2003. Nutritional regulation of milk fat synthesis. Annu. Rev. Nutr. 23:203-227.

Cabrita, A. R. J., R. J. B. Bessa, S. P. Alves, R. J. Dewhurst, and A. J. M. Fonseca. 2007. Effects of dietary protein and starch on intake, milk production and milk fatty acid profiles of dairy cows fed corn silage-based diets. J. Dairy Sci. 90:1429-1439.

Cabrita, A. R. J., A. J. M. Fonseca, R. J. Dewhurst, and E. Gomes. 2003. Nitrogen supplementation of corn silages. 2. Assessing rumen function using fatty acid profiles of bovine milk. J. Dairy Sci. 86:4020-4032.

CVB (Centraal Veevoederbureau). 2004. Tabellenboek Veevoeding 2004. Voedernormen landbouwhuisdieren en voederwaarden veevoeders. CVB-reeks nr. 27. CVB, Lelystad, the Netherlands.

Chilliard, Y., A. Ferlay, and M. Doreau. 2000. Effect of different types of forages, animal fat or marine oils in cow's diet on milk fat secretion and composition, especially conjugated linoleic acid (CLA) and polyunsaturated fatty acids. Livest. Prod. Sci. 70:31-48.

Chilliard, Y., A. Ferlay, J. Rouel, and G. Lamberet. 2003. A review of nutritional and physiological factors affecting goat milk lipid synthesis and lipolysis. J. Dairy Sci. 86:1751-1770.

Choumei, Y., A. K. Kahi, and H. Hirooka. 2006. Fit of Wood's function to weekly records of milk yield, total digestible nutrient intake and body weight changes in early lactation of multiparous Holstein cows in Japan. Livest. Sci. 104:156-164.

Craninx, M., V. Fievez, B. Vlaeminck, and B. De Baets. 2008. Artificial neural network models of the rumen fermentation pattern in dairy cattle. Comput. Electron. Agric. 60:226-238.

Croom, W. J., D. E. Bauman, and C. L. Davis. 1981. Methylmalonic acid in low-fat milk syndrome. J. Dairy Sci. 64:649-654.

Elgersma, A., S. Tamminga, and G. Ellen. 2006. Modifying milk composition through forage. Anim. Feed Sci. Technol. 131:207-225.

Ferlay, A., B. Martin, Ph. Pradel, J. B. Coulon, and Y. Chilliard. 2006. Influence of grass-based diets on milk fatty acid composition and milk lipolytic system in Tarentaise and Montbéliarde cow breeds. J. Dairy Sci. 89:4026-4041.

Garnsworthy, P. C., L. L. Masson, A. L. Lock, and T. T. Mottram. 2006. Variation of milk citrate with stage of lactation and de novo fatty acid synthesis in dairy cow. J. Dairy Sci. 89:1604-1612.

Grummer, R. R. 1991. Effect of feed on the composition of milk fat. J. Dairy Sci. 74:3244-3257.

Grzesiak, W., P. Blaszczyk, and R. Lacroix. 2006. Methods of predicting milk yield in dairy cows-Predictive capabilities of Wood's lactation curve and artificial neural networks (ANNs). Comput. Electron. Agric. 54:69-83.

Horning, M. G., D. B. Martin, A. Karmen, and P. R. Vagelos. 1961. Fatty acid synthesis in adipose tissue. II. Enzymatic synthesis of branched chain and odd-numbered fatty acids. J. Biol. Chem. 236:669-672.

Kay, J. K., W. J. Weber, C. E. Moore, D. E. Bauman, L. B. Hansen, H. Chester, B. A. Crooker, and L. H. Baumgard. 2005. Effects of week of lactation and genetic selection for milk yield on milk fatty acid composition in Holstein cows. J. Dairy Sci. 88:3886-3893.

Kelsey, J. A., B. A. Corl, R. J. Collier, and D. E. Bauman. 2003. Effect of breed, parity and stage of lactation on conjugated linoleic acid (CLA) in milk fat from dairy cows. J. Dairy Sci. 86:2588-2597.

Littell, R. C., P. R. Henry, and C. B. Ammerman. 1998. Statistical analysis of repeated measures data using SAS procedures. J. Anim. Sci. 76:1216-1231.

Lourenço, M., S. De Smet, K. Raes, and V. Fievez. 2007a. Effect of botanical composition of silages on rumen fatty acid metabolism and fatty acid composition in longissimus muscle and subcutaneous fat of lambs. Animal 1:911-921.

Lourenco, M., G. Van Ranst, S. De Smet, K. Raes, and V. Fievez. $2007 \mathrm{~b}$. Effect of grazing pastures with different botanical compo- 
sition by lambs on rumen fatty acid metabolism and fatty acid pattern of longissimus muscle and subcutaneous fat. Animal 1:537-545.

Macciotta, N. P. P., D. Vicario, and A. Cappio-Borlino. 2005. Detection of different shapes of lactation curve for milk yield in dairy cattle by empirical mathematical models. J. Dairy Sci. 88:1178-1191.

Massart-Leën, A. M., E. Roets, G. Peeters, and R. Verbeke. 1983. Propionate for fatty acid synthesis by the mammary gland of the lactating goat. J. Dairy Sci. 66:1445-1454.

Palmquist, D. L., A. D. Beaulieu, and D. M. Barbano. 1993. ADSA Foundation Symposium: Milk fat synthesis and modification. Feed and animal factors influencing milk fat composition. J. Dairy Sci. 76:1753-1771.

Quinn, N., L. Killen, and F. Buckley. 2005. Empirical algebraic modelling of lactation curves using Irish data. Irish J. Agric. Food Res. 44:1-13.

Quinn, N., L. Killen, and F. Buckley. 2006. Empirical algebraic modelling of live weight of Irish dairy cows over lactation. Livest. Sci. 103:141-147.

Raes, K., L. Haak, A. Balcaen, E. Claeys, D. Demeyer, and S. De Smet. 2004. Effect of linseed feeding at similar linoleic acid levels on the fatty acid composition of double muscled Belgium Blue young bulls. Meat Sci. 66:307-315.

Rigout, S., C. Hurtaud, S. Lemosquet, A. Bach, and H. Rulquin. 2003. Lactational effect of propionic acid and duodenal glucose in cows. J. Dairy Sci. 86:243-253.

Smith, S. 1994. The animal fatty acid synthase: One gene, one polypeptide, seven enzymes. FASEB J. 8:1248-1259.
Tamminga, S., W. M. Van Straalen, A. J. P. Subnel, R. G. M. Meijer, A. Steg, C. J. G. Wever, and M. C. Block. 1994. The Dutch Protein Evaluation System: The DVE/OEB-system. Livest. Prod. Sci. 40:139-155.

van Es, A. J. H. 1978. Feed evaluation for ruminants. I. The systems in use from May 1977 onwards in The Netherlands. Livest. Prod. Sci. 5:331-345.

van Knegsel, A. T. M., H. van den Brand, J. Dijkstra, W. M. van Straalen, M. J. W. Heetkamp, and B. Kemp. 2007. Dietary energy source in dairy cows in early lactation: energy partioning and milk composition. J. Dairy Sci. 90:1467-1476.

Van Nespen, T., B. Vlaeminck, W. Wanzele, W. Van Straalen, and V. Fievez. 2005. Use of specific milk fatty acids as diagnostic tool for rumen acidosis in dairy cows. Commun. Appl. Biol. Sci. 70:277-280.

Verbeke, R., M. Lauryssens, and G. Peeters. 1959. Incorporation of DL- $\left[1-{ }^{14} \mathrm{C}\right]$ leucine and $\left[1-{ }^{14} \mathrm{C}\right]$ isovaleric acid into milk constituents by the perfused cow's udder. Biochem. J. 73:24-29.

Vlaeminck, B., C. Dufour, A. M. van Vuuren, A. R. J. Cabrita, R. J. Dewhurst, D. Demeyer, and V. Fievez. 2005. Potential of oddand branched-chain fatty acids as microbial markers: Evaluation in rumen contents and milk. J. Dairy Sci. 88:1031-1041.

Vlaeminck, B., V. Fievez, A. R. J. Cabrita, A. J. M. Fonseca, and R. J. Dewurst. 2006b. Factors affecting odd- and branched- fatty acids in milk: A review. Anim. Feed Sci. Technol. 131:389-417.

Vlaeminck, B., V. Fievez, S. Tamminga, R. J. Dewhurst, A. van Vuuren, D. De Brabander, and D. Demeyer. 2006a. Milk odd- and branched-chain fatty acids in relation to the rumen fermentation pattern. J. Dairy Sci. 89:3954-3964.

Wood, P. D. P. 1967. Algebraic model of the lactation curve in cattle. Nature 216:164-165. 